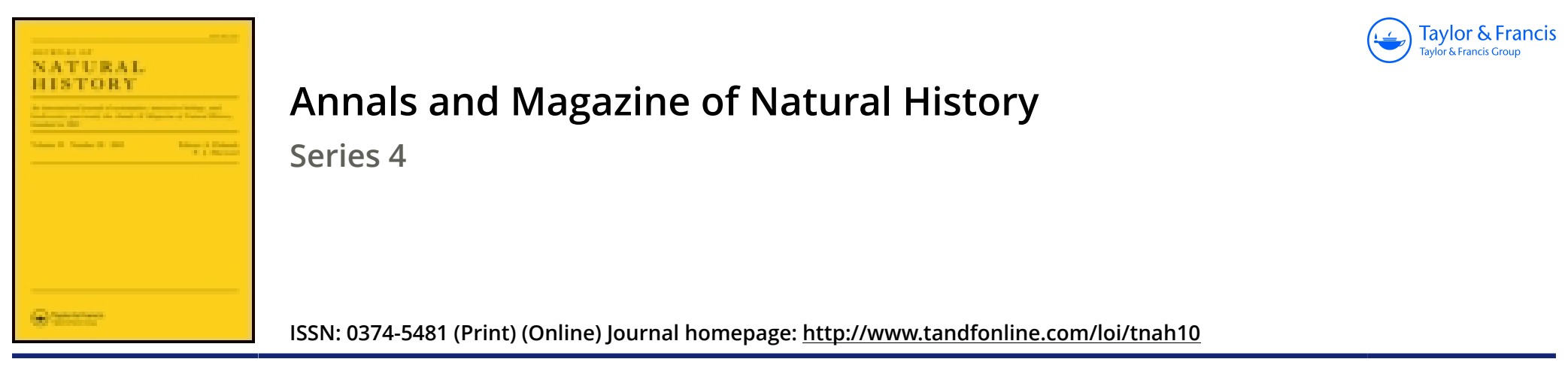

\title{
XXIX.-On the production of the Sexes in bees
}

\section{Félix Plateau D.Sc.}

To cite this article: Félix Plateau D.Sc. (1868) XXIX.-On the production of the Sexes in bees, Annals and Magazine of Natural History, 2:10, 252-255, DOI: 10.1080/00222936808695798

To link to this article: http://dx.doi.org/10.1080/00222936808695798

曲 Published online: 16 Oct 2009.

Submit your article to this journal $\widetilde{ }$

III Article views: 3

Q View related articles $\sqsubset$ 
and which are at any rate in the same category, viz. a Sigalion, a Syllis, an Autolytus, an Amage, and a Polycirrus.

I may also remark, in passing, with reference to some of the other known forms found in this collection, that the Halosydna Jeffreysii, Lankester*, is $H$. gelatinosa, Sars $\dagger$, as mentioned in Dr. Günther's Zoological Record for 1866, and that I have not yet been able to make out a specific difference between Leodice norvegica, Linn., and Eunice Harassii, Aud. \& Ed.‡

In addition to the Annelids proper, there were some Planarians, Ommatopleans, Borlasians, and a very remarkable form allied to the latter group, with a bifid proboscis-besides a boring Sipunculus, lodged in its cavity inside a fragment of shell.

XXIX.-On the Production of the Sexes in Bees. By Fúlix Plateau, D.Sc.

To the Editors of the Annals and Magazine of Natural History.

Gentlemen,

Ghent, Sept. 9, 1868.

Having been occupied for a long time with investigations upon the parthenogenesis of the Invertebrata, I have read with eagerness the interesting notice by M. von Siebold "On the Law of Development of the Sexes in Insects," in which the learned Professor endeavours to refute the assertions and experiments of M. Landois.

The theories of Dzierzon and of Von Siebold, ingenious as they are, and notwithstanding the numerous facts which are cited in their support, seem nevertheless to be so much in contradiction to our general knowledge of the reproduction in the higher animals, that researches such as those of M. Landois should be received with favour, and we ought to take care not to reject them without having exhausted all possible arguments in connexion with them.

M. von Siebold, indeed, passes over in complete silence some very important observations which seem to me to be entirely in favour of M. Landois. Androgynous or hermaphrodite bees have been remarked long since by a schoolmaster named Lucas; - and more recently this monstrosity has been observed by MM. Doenhoff, Menzel, and Engster;

* Trans. Linn. Soc. vol. xxv. p. 377, tab. 51. figs. 12, $19,26$.

+ Beskriv. og Jagtt. \&c. 1835, p. 63, pl. 9. fig. 25.

$\ddagger$ Hist. Nat. du Litt. de la France, ii. p. 141, pl. 3. fig. 5, 6, 7, 10, \& 11 . 
lastly, in 1864 and $1865, M$. von Siebold himself and M. Leuckart paid attention almost simultaneously to this singular fact, which is far from being rare *.

I shall not enter upon this subject in much detail; it will be sufficient for me to say that in the androgynous bees there is a mixture of male and female characters varying from one individual to another, and which is met with in a number of organs both internal and external; very often we find simultaneously, on each side of the body, a few testicular coils and a few ovarian tubes, a well-developed male copulatory apparatus, and a sting, although the sting is wanting in the male. According to M. Leuckart all the hermaphrodite individuals (of which he examined about fifty) must be regarded as workers presenting certain male characters.

Here, therefore, we have bees in which the genital and other organs have been developed at once in the male and in the female direction-an evident proof that the larva has no sex before a certain period (the sixth day), and that an influence which exists outside it causes it to deviate subsequently, either towards the male or the female type.

Moreover certain animals, such as the Aphides, according to the beautiful investigations of M. Balbiani $\dagger$, of which M. von Siebold likewise says nothing, commence by having the two sexes united and in the same state of development. The viviparous Aphides are and remain hermaphrodites: in the oviparous Aphides, when the embryo is to become a female insect, the male organs retain their rudimentary character, while the female organs increase; on the contrary, when the individual is to be a male, the female part of the original hermaphrodite apparatus becomes transformed into a true testicle, the cells which it contains becoming fusiform follicles filled with spermatic corpuscles. Finally, the male apparatus does not disappear, and exists, after birth, in the oviparous individuals of both sexes with characters which scarcely differ in any respect from those which it presents in the viviparous Aphides.

To return from this to the causes which may determine the formation of the sexes in bees. It is possible that M. Landois

* Von Siebold, "Ueber Zwitterbienen," Zeitsehr. für wiss. Zool, xiv. p. 73 ; Bibl. Univ. Archives, xx. p. 64. Leuckart, "Ueber Bienenzwitter," Bericht über die Versammlung deutsch. Naturf. und Aerzte, 1865, iii. p. 173 ; Bibl. Univ. Arehives, xxv. p. 172.

$\dagger$ Comptes Rendus, tome lxii. pp. 1231, 1285, 1390; Ann. \& Mag. Nat. Hist. ser. 3. xviii. pp. 65 and 106 (but see M. Claparède's observations on Balbiani's researches, Ann. des Sci. Nat. $5^{\text {e }}$ sér. vii. p. 21 , and Ann. \& Mag. Nat. Hist. ser. 3. xix. p. 360).

Ann.\& Mag. N. Hist. Ser. 4. Vol.ii. 
254 Dr. F. Plateau on the Production of the Sexes in Bees.

deceives himself in ascribing the production of males to insufficiency of nourishment; but would not the intimate composition of this nourishment have an influence? Given a very young worker-larva, the genital organs of which may equally become male or female, as is indicated by the hermaphrodite bees, since a special nourishment may make of it a queen, according to Schirach* and the bee-keepers, one is led to assume, until incontestable evidence to the contrary is obtained, that the food may also force the male reproductive organs, which exist in a latent state, to become developed to the exclusion of the others.

Would not the form of the cells also play its part? for it is certainly not without motive that the lids of the male cells are convex.

Permit me to add a few words with regard to the very recent investigations of MM. Sanson and Bastian, which, far from invalidating those of M. Landois as those authors think, only serve to confirm them, in my opinion.

MM. Sanson and Bastian † cut away from a male cell the bottom part which bears the egg, remove the bottom of a worker-cell, and substitute for it the preceding piece, which they fix by passing a hot needle along its margins.

Like M. Landois and M. Bessels, who have made analogous experiments, MM. Sanson and Bastian remove the queen, so as to avoid mistaking for the eggs which they have placed artificially others subsequently laid by the female.

The ninety-three male eggs introduced by the method just described were regularly expelled by the workers, from which MM. Sanson and Bastian conclude that the experiments of M. Landois are erroneous.

But we may remark that the process employed by this lastmentioned observer is entirely different. Knowing well that the worker-bees promptly cleanse the cells of all foreign bodies, he carefully avoided mutilating the cells after the fashion of MM. Sanson and Bastian, whose handiwork, which would certainly be very coarse for bees, would be immediately recognized by them. He delicately removed the egg with a very small fragment of wax, and stuck it into the interior of the new cell, by means of this little fragment, in the most natural position possible. Under these conditions the author saw the eggs of workers transported into male-cells give birth to drones.

MM. Sanson and Bastian introduced into an artificial hive,

* Histoire Naturelle de la Reine des Abeilles. Trad. Blassière, 1771, p. 45.

+ Comptes Rendus, tom. 1xvii, p. 51. 
composed exclusively of male cells selected elsewhere, some living workers and their queen; all the bees produced in these cells were workers. I see nothing in this opposed to the theory of M. Landois; the eggs deposited in the drone-cells furnished workers because the bees had furnished them, after deposition, with worker food. We may add, in support of this opinion, that the queen had deposited two eggs which the workers destined to the production of males, as they closed the cells with convex lids. But they afterwards destroyed these eggs, because it was exactly at the season (very illchosen by MM. Sanson and Bastian) when they kill the drones.

Lastly, what, it seems to me, must give the cause to $\mathbf{M}$. Landois, is that MM. Sanson and Bastian have seen deposited in worker-cells eggs which gave origin to males. These two naturalists, indeed, endeavour to explain the fact by means of Dzierzon's theory. The queen, they say, was old, and her spermatic reservoir no longer contained a sufficiency of spermatozoids, for it was semitransparent. Now, if the seminal receptacle is opaque when it is completely full, it is perfectly transparent when empty, and it seems to me that when we find it only semitransparent, it will still contain far too many spermatozoids to allow the observer to think that the eggs have not been fecundated.

XXX.-On the manner of Fertilization of the Scarlet Runner and Blue Lobelia. By T. H. FArrer, Esq.

To the Editors of the Annals and Magazine of Natural History.

Gentremen;

The following notes of observations on the fertilizing-apparatus of the scarlet runner and the common blue lobelia, made by one who has not the slightest pretence to scientific knowledge, would never have been sent to the press, but for the kind suggestion of Mr. Charles Darwin, to whom they have been communicated. That these interesting facts, if not mentioned by previous observers, should have escaped his notice never occurred to me for a moment, although at the time this paper was written I had not seen his papers on the fertilization of the kidney bean in the 'Gardeners' Chronicle' of the 24th of October 1857 and the 14th November 1858, which he has kindly sent me. In these papers the structure and functions of the kidney bean are fully given, with his own interesting experiments; and though in them the details of the lobelia 